\section{Pertumbuhan Tanaman Cabai Rawit (Capsicum frutescens L.) terhadap Pemberian Pupuk Organik Cair Limbah Pisang Kepok}

Hilda Karim1, A. Irma Suryani², Yusnaeni Yusuf³, Nur Afni Khaer Fatah4

Universitas Negeri Makassar, 1,2,3,4

Email: hilda.karim@unm.ac.id

Abstrak. Penelitian ini bertujuan untuk mengetahui pengaruh pupuk organik cair limbah pisang kepok (Musa paradisiaca forma typica) terhadap pertumbuhan tanaman cabai rawit (Capsicum frutescens L.). Berdasarkan hasil penelitian, dosis pupuk organik cair berpengaruh nyata terhadap pertumbuhan vegetatif (pertumbuhan panjang akar, tinggi batang dan jumlah daun tanaman cabai rawit) sementara pada pertumbuhan generatif (rata-rata jumlah bunga, jumlah buah, berat basah tanaman, dan berat basah buah), tanaman cabai rawit menunjukkan bahwa faktor dosis memberikan pengaruh yang nyata terhadap jumlah bunga, jumlah buah, berat basah tanaman, dan berat basah buah cabai rawit.

Kata Kunci: Pupuk Organik Cair, Limbah Pisang Kepok, Tanaman Cabai Rawit

\section{INDONESIAN JOURNAL OF FUNDAMENTAL SCIENCES (IJFS)}

\section{E-ISSN: 2621-6728 \\ P-ISSN: 2621-671X}

Submitted: July, $24^{\text {th }}, 2019$

Accepted : September, $22^{\text {th }}, 2019$

Abstract. This study aims to study the effect of banana (Musa paradisiaca forma typica) liquid organic fertilizer on the growth of chili (Capsicum frutescens L.). Based on the results of the study, the dose of organic fertilizer increased for vegetative growth (growth of root length, stem height and number of leaves of chili) while in generative growth (average number of flowers, number of fruits, many plants, and many plants), chili plants produce facts, produces large quantities, number of plants, wet weight of plants, and wet weight of chili. 


\section{PENDAHULUAN}

Indonesia dikenal sebagai negara agraris sehingga sektor pertanian menjadi andalan utama mata pencaharian penduduk Indonesia (Roidah, 2013). Tanaman unggulan pertanian salah satunya adalah cabai rawit (Capsicum frutescens L.). Tanaman cabai ini merupakan tanaman hortikultura yang multifungsi, dapat digunakan sebagai bumbu masak, saus atau sambal dan bahan campuran obatobatan serta banyak kandungan gizi (Karim, H., et al, 2016). Berdasarkan kandungan tersebut, cabai rawit menjadi sayuran yang dibutuhkan oleh semua kalangan masyarakat. Produksi cabai rawit di Provinsi Sulawesi Selatan dengan rata-rata 5 tahun terakhir (2012-2016) yaitu 21.583 ton dengan persentase pertumbuhan tahun 2016 selama 2015 yaitu 3,66\% sedangkan persentase nasional dapat mencapai 5,29\% (BPS, 2011).

Penggunaan pupuk anorganik menjadi salah satu teknik yang sering digunakan petani untuk menghasilkan tanaman cabai rawit yang subur dan berkualitas, karena mudah diaplikasikan dan mudah diperoleh. Namun kendala yang kemudian muncul adalah harus membutuhkan biaya yang besar. Penggunaan pupuk anorganik secara terus-menerus mengakibatkan terjadinya penurunan kualitas tanah (Mahasari, 2008). Penggunaan pupuk anorganik yang berlebihan dapat merusak sifat fisik, biologi dan kimia tanah.

Berdasarkan hal tersebut maka penelitian ini menggunakan POC dari limbah Pisang Kepok yang diharapkan dengan penggunaannya dapat memperbaiki sifat fisik, biologi dan kimia tanah. Penelitian sebelumnya, telah dilakukan analisis terhadap kandungan unsur hara makro dan dari hasil fermentasi limbah kulit pisang, terkandung unsur hara makro N, P, K, Ca, dan Mg yang memenuhi standar yang ditetapkan Pemerintah sehingga dapat digunakan sebagai pupuk organik (Karim, H., et al, 2018) sehingga di penelitian ini, hasil fermentasi limbah pisang kapok akan diujikan pada tanaman cabai rawit (Capsicum frutescens L.), untuk mengamati pertumbuhannya.

Pupuk organik cair adalah pupuk yang berasal dari bahan organik yang bentuknya cair atau larutan yang mudah larut berisi satu atau lebih unsur yang dibutuhkan tanaman. Selain itu pemberiannya dapat lebih merata dan kepekatannya dapat diatur sesuai dengan kebutuhan tanaman (Parnata, 2004). Menurut Rizqiani, et al (2006), tanaman yang diberi pupuk organik cair dapat menghasilkan fotosintat yang lebih banyak dibandingkan dengan tanaman yang tidak diberi pupuk organik cair (kontrol). Salah satu yang bisa dimanfaatkan untuk pebuatan pupuk organic cair adalah limbah dari kulit pisang. Pati yang terkandung dalam umbi batang pisang dapat dipergunakan sebagai sumber karbohidrat bahkan bisa dikeringkan untuk menjadi abu. Abu dari umbi ini mengandung soda yang dapat digunakan sebagai bahan pembuatan sabun dan pupuk (Munadjim,1988).

\section{METODE PENELITIAN}

Penelitian ini dilaksanakan di Lingkungan Batili Dalam, Kelurahan Galonta, Kecamatan Enrekang, Kabupaten Enrekang pada bulan April sampai Juli 2019. Adapun tahapan penelitian sebagai berikut: 
a. Pembuatan Pupuk Organik Cair Limbah Pisang Kepok, pengumpulan limbah pisang kepok (kulit pisang dan bonggol pisang). Setelah tercampur sempurna larutan tersebut dimasukkan ke dalam bioreaktor yang terbuat dari jerigen lalu ditutup rapat. Kemudian dibiarkan atau diamkan selama 15 hari dan 30 hari. Pupuk cair yang telah dihasilkan dari proses fermentasi selanjutnya disaring.

b. Persiapan Benih Cabai Rawit (Capsicum frutescens L.). Perlakuan terhadap benih dilakukan denga merendam benih dalam air hangat dan menambahkan juga larutan fungisida dan bakterisida agar steril dari hama dan penyakit. Perendaman benih sebaiknya 2-3 jam. Kemudian disemaikan satu per satu sedalam 1,0 -1,5 cm, lalu ditutup dengan tanah tipis.

c. Persiapan Penanaman Benih di Polybag

d. Seleksi dan Perawatan Bibit

e. Perlakuan, pemupukan kepok dilakukan setelah cabai rawit berumur 2 minggu setelah bibit ditanam di polybag. Pupuk disiram pada tanah dengan jarak $5 \mathrm{~cm}$ dari batang tanaman cabai dilakukan secara melingkar. Penyiraman pupuk dilakukan 7 hari sekali. Pemupukan dilakukan pada sore hari. Analisis data hasil pengamatan kemudian dianalisis dengan menggunakan sidik ragam (ANOVA) Rancangan Acak Kelompok Faktorial (RAKF). Jika terdapat faktor yang memberikan pengaruh nyata ( $F$ hitung $\geq F$ tabel), maka dilanjutkan dengan uji Post Hoc yaitu Tukey Honestly Significant Differences (HSD) atau Uji Beda Nyata Jujur (BNJ) yang digunakan untuk menguji perbandingan berbagai kelompok rata-rata. Analisis data menggunakan program SPSS Statistic 22.

\section{HASIL PENGAMATAN}

Hasil penelitian pengaruh lama fermentasi dan dosis pupuk organik cair limbah pisang kepok (Musa paradisiaca forma typica) terhadap pertumbuhan vegetatif (panjang akar, tinggi batang, jumlah daun) dan produksi tanaman cabai rawit (jumlah bunga, jumlah buah, berat basah tanaman, dan berat basah buah).

\section{Pertumbuhan Vegetatif}

Berdasarkan analisis ragam rata-rata panjang akar, tinggi batang, dan jumlah daun tanaman cabai rawit menunjukkan bahwa faktor lama fermentasi ( $F$ ) dan interaksi antara faktor $\mathrm{F}$ dan faktor $\mathrm{D}$ tidak memberikan pengaruh yang nyata. Faktor dosis memberikan pengaruh yang nyata terhadap pertumbuhan panjang akar, tinggi batang dan jumlah daun tanaman cabai rawit, sehingga diperlukan uji lanjut yang hasilnya sebagai berikut pada Gambar 1, 2, dan 3. 


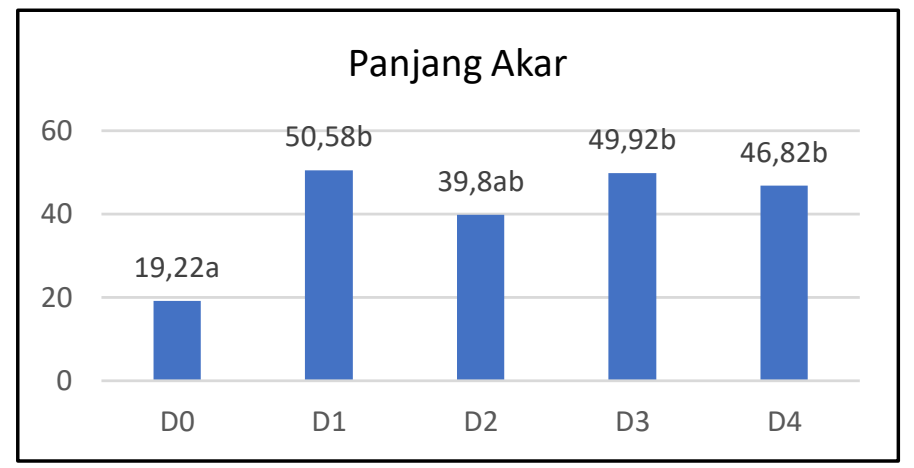

Gambar 1. Nilai Rataan Panjang Akar Tanaman Cabai Rawit

Keterangan:

Do= kontrol negatif/tanpa perlakuan;

D1 = kontrol positif/NPK;

$\mathrm{D} 2=200 \mathrm{ml} \mathrm{POC}$;

$\mathrm{D} 3=400 \mathrm{ml} \mathrm{POC}$;

$\mathrm{D} 4=600 \mathrm{ml} \mathrm{POC}$.

Huruf yang sama menunjukkan "tidak berbeda nyata". Huruf yang berbeda menunjukkan "sangat berbeda nyata" berdasarkan uji lanjut Tukey $\alpha 0.05$.

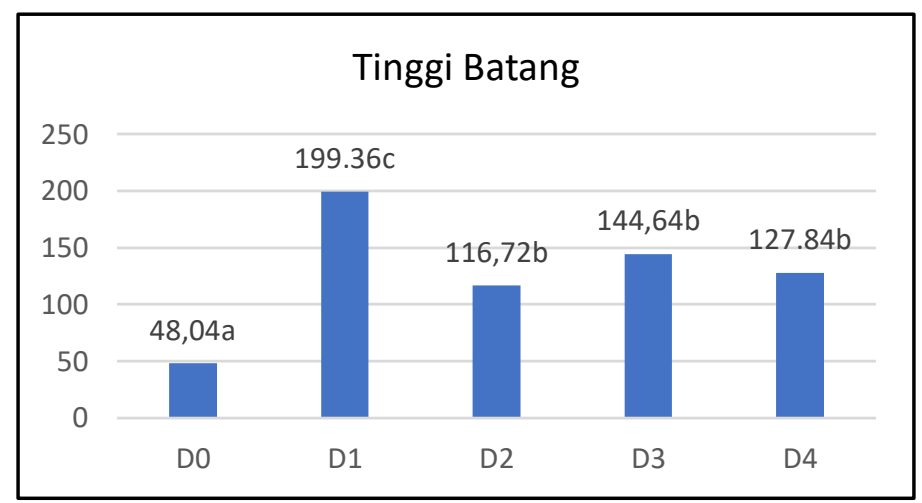

Gambar 2. Nilai Rataan Tinggi Batang Tanaman Cabai Rawit

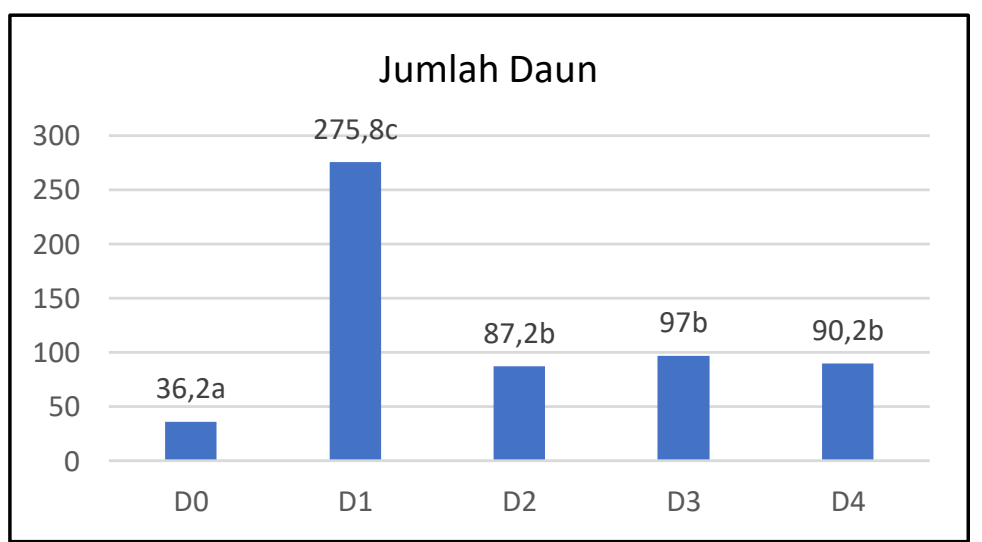

Gambar 3. Nilai Rataan Jumlah Daun Tanaman Cabai Rawit 
Hasil uji lanjut Tukey Honestly Significant Difference (HSD) yang dapat pula dilihat pertambahannya secara visual, pada parameter panjang akar menunjukkan bahwa perlakuan pupuk organik cair (D2) tidak berbeda nyata dengan kontrol positif/NPK dan kontrol negatif/tanpa perlakuan. Perlakuan pupuk organik cair (D3 dan D4) tidak berbeda nyata dengan kontrol positif/NPK dan sangat berbeda nyata dengan kontrol negatif/tanpa perlakuan. Parameter tinggi batang dan jumlah daun menunjukkan bahwa perlakuan pemberian POC sangat berbeda nyata dengan kontrol positif/NPK dan kontrol negatif/tanpa perlakuan.

\section{Pertumbuhan Generatif}

Berdasarkan analisis ragam rata-rata jumlah bunga, jumlah buah, berat basah tanaman, dan berat basah buah tanaman cabai rawit menunjukkan bahwa faktor dosis memberikan pengaruh yang nyata terhadap jumlah bunga, jumlah buah, berat basah tanaman, dan berat basah buah cabai rawit, sehingga diperlukan uji lanjut yang hasilnya sebagai berikut (Gambar 4, 5, 6, dan 7).

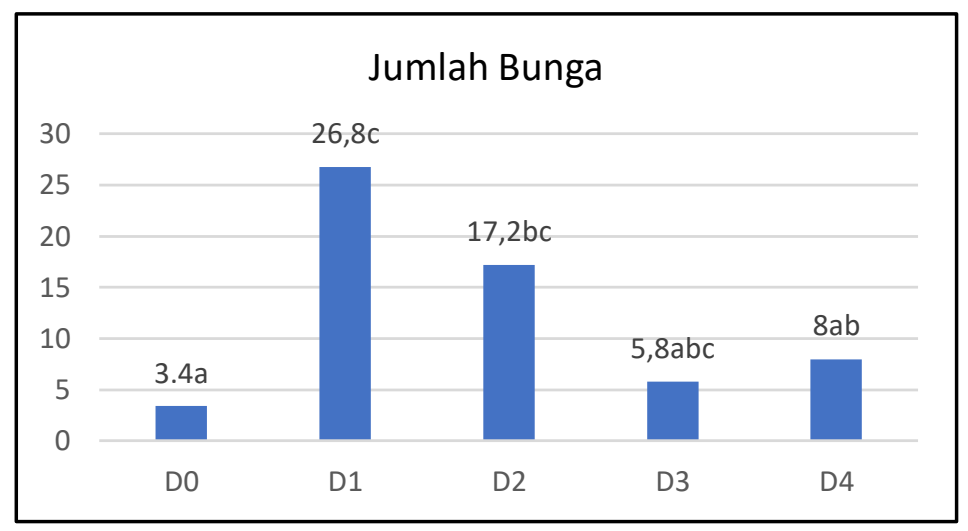

Gambar 4. Nilai Rataan Jumlah Bunga Tanaman Cabai Rawit

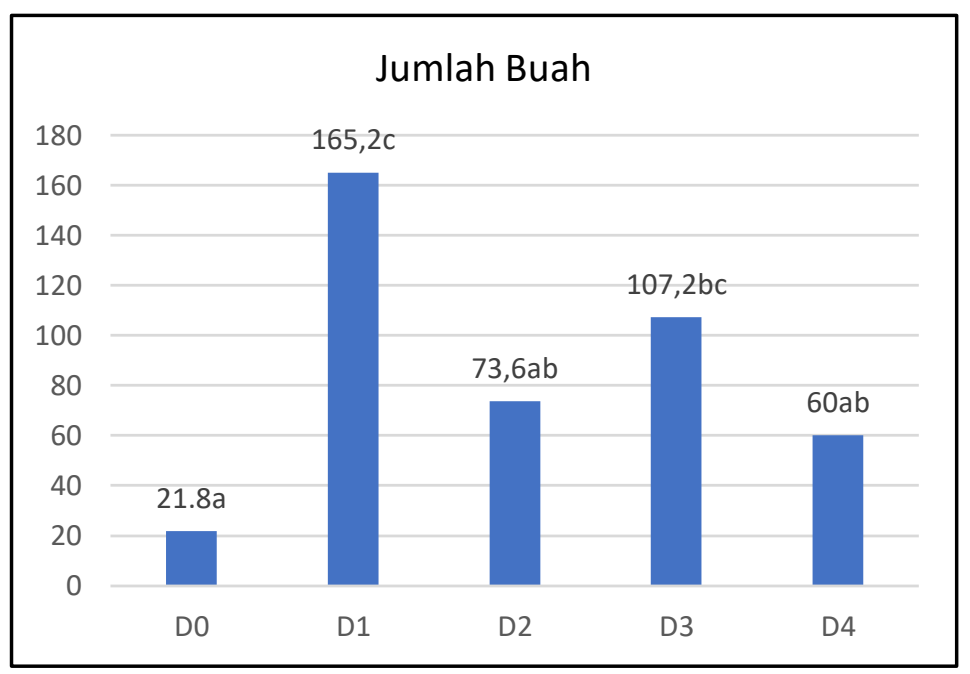

Gambar 5. Nilai Rataan Jumlah Buah Tanaman Cabai Rawit 
Hasil uji lanjut Tukey HSD yang dapat pula dilihat pertambahannya secara visual, pada parameter jumlah bunga menunjukkan bahwa perlakuan pupuk organik cair (D2) tidak berbeda nyata dengan kontrol positif/NPK. (D3) tidak berbeda nyata dengan kontrol positif/NPK dan kontrol negatif/tanpa perlakuan. (D4) tidak berbeda nyata dengan kontrol negatif/tanpa perlakuan. Parameter jumlah buah, menunjukkan bahwa perlakuan pupuk organik cair (D2 dan D4) tidak berbeda nyata dengan kontrol negatif/tanpa perlakuan. Sedangkan (D3) tidak berbeda nyata dengan kontrol positif/NPK.

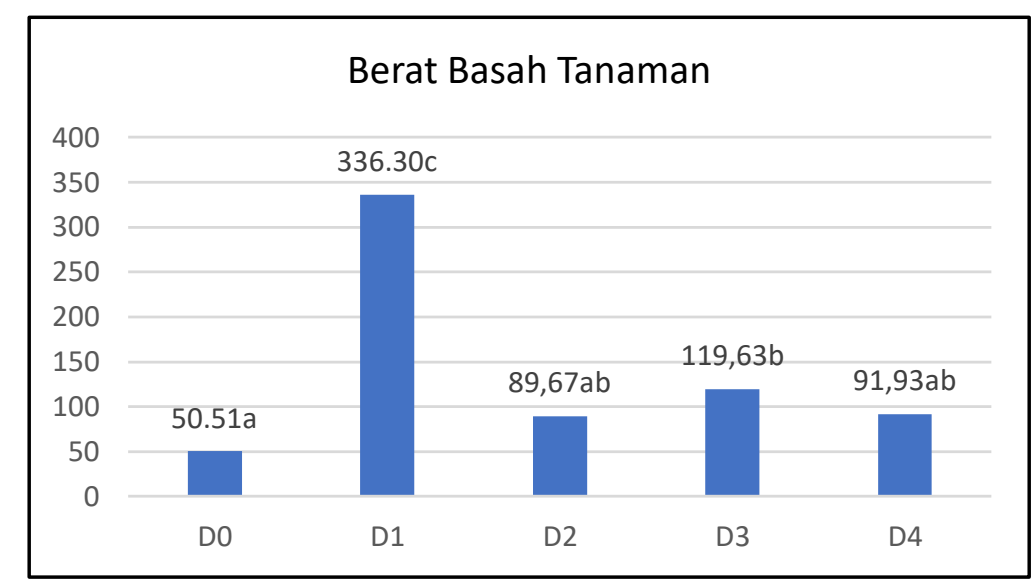

Gambar 6. Nilai Rataan Berat Basah Tanaman Cabai Rawit

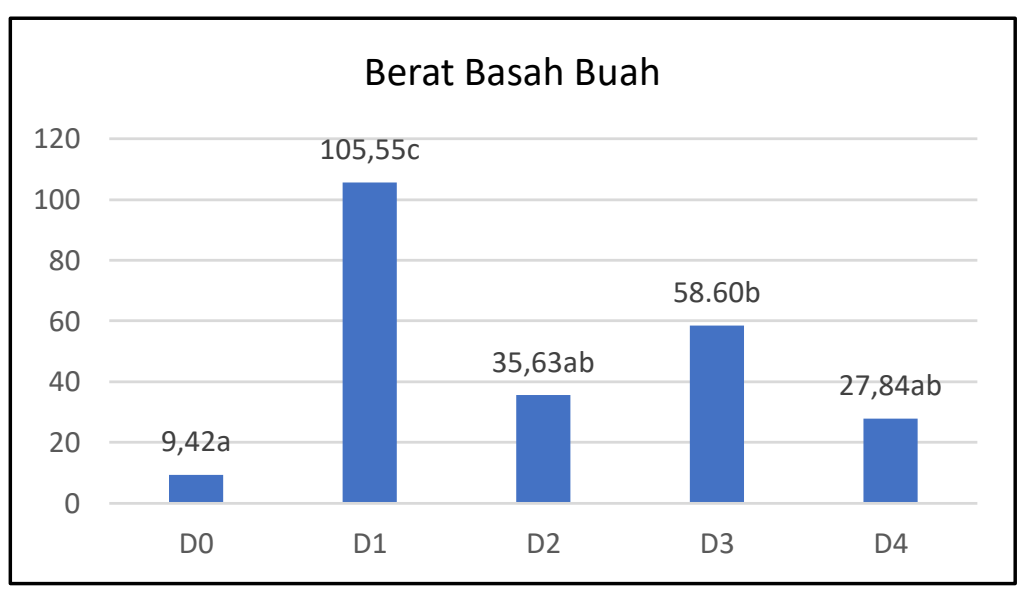

Gambar 7. Nilai Rataan Berat Basah Buah Cabai Rawit

Hasil uji lanjut Tukey HSD yang dapat pula dilihat pertambahannya secara visual, pada parameter berat basah tanaman dan berat basah buah menunjukkan bahwa perlakuan pupuk organik cair (D2, D3, dan D4) tidak berbeda nyata dengan kontrol negatif/tanpa perlakuan. Dengan demikian dapat disimpulkan bahwa pemberian pupuk organik cair limbah pisang kepok tidak memberikan pengaruh yang nyata.

Hasil analisis sidik ragam pada pertumbuhan vegetatif menunjukkan bahwa faktor lama fermentasi dan interaksi antara lama fermentasi dan dosis pupuk organik 
cair tidak memberikan pengaruh yang nyata. Hasil uji lanjut pertumbuhan vegetatif nilai yang tertinggi adalah kontrol positif/NPK (D1) tetapi tidak berbeda nyata dengan perlakuan pupuk organik cair (D2, D3, D4) dan berbeda nyata dengan kontrol negatif/tanpa perlakuan.

Hal ini disebabkan kandungan unsur hara pada pupuk organik cair yang diberikan pada tanaman kurang mencukupi kebutuhan tanaman cabai rawit. Tanaman cabai memiliki kebutuhan terbesar untuk Nitrogen (31\%) dan Kalium (40\%) dibandingkan tanaman hortikultura lain, dalam kaitannya dengan jumlah total nutrisi yang diserap (Golcz et al, 2012). Penelitian ini sejalan dengan hasil penelitian yang dilakukan oleh Hasriani (2018) yaitu kandungan NPK pada fermentasi POC 15 hari $0.21 \% \mathrm{~N} ; 2.54 \% \mathrm{P} ; 2.41 \% \mathrm{~K}$ dan fermentasi POC 30 hari yaitu $0.25 \% \mathrm{~N} ; 0.52 \% \mathrm{P} ; 3.22 \% \mathrm{~K}$. Sedangkan kadar pupuk NPK anorganik yang digunakan pada kontrol positif/NPK yaitu 16\% N (Nitrogen), 16\% $\mathrm{P}_{2} \mathrm{O}_{5}$ (Phosphate), $16 \% \quad \mathrm{~K}_{2} \mathrm{O}$ (Kalium), $0.5 \% \mathrm{MgO}$ (Magnesium), dan 6\% CaO (Kalsium).

Meskipun unsur hara pupuk organik cair kurang dibandingkan pupuk anorganik namun dapat memacu pertumbuhan dilihat dari tidak berbeda nyata dengan kontrol positif/NPK. Hal ini dikarenakan adanya bahan organik yang mampu memperbaiki sifat fisika, kimia, dan biologi tanah. Perbaikan terhadap sifat fisik seperti menggemburkan tanah, memperbaiki aerasi dan drainase, meningkatkan ikatan antar partikel, meningkatkan kapasitas menahan air, mencegah erosi dan longsor, dan merevitalisasi daya olah tanah. Fungsi pupuk organik terhadap sifat kimia yaitu meningkatkan kapasitas tukar kation, meningkatkan ketersediaan unsur hara, dan meningkatkan proses pelapukan bahan mineral. Adapun terhadap sifat biologi yaitu menjadikan sumber makanan bagi mikroorganisme tanah seperti fungi, bakteri, serta mikroorganisme menguntungkan lainnya, sehingga perkembangan organisme tersebut menjadi lebih cepat (Hadisuwito, 2008). Kandungan nitrogen yang tidak mencukupi dikarenakan bahan-bahan yang digunakan untuk pembuatan pupuk organik cair mengandung jumlah unsur yang kurang sehingga pupuk organik cair yang dibuat tidak dapat menstimulasi pertumbuhan vegetatif tanaman (akar, batang, daun) secara maksimal. Nitrogen (N) diperuntukkan dalam pembentukan atau pertumbuhan bagian-bagian vegetatif tanaman seperti daun, batang, dan akar.

Wardhani et al. (2014) menyatakan bahwa perlakuan yang tidak mengandung pupuk anorganik akan menunjukkan pertumbuhan yang lebih lambat dibandingkan dengan perlakuan lain yang mengandung pupuk anorganik. Penyerapan unsur hara oleh tanaman tidak dapat diserap sekaligus untuk pertumbuhan panjang akar, tinggi dan jumlah daun. Pada awal pertanaman unsur hara akan tertuju pada pertumbuhan tinggi tanaman dan saat mendekati masa akhir vegetatif unsur hara akan diserap untuk pertumbuhan diameter batang. Hasil ini sejalan dengan hasil penelitian yang dilakukan oleh Wahyuningratri et al. (2017) menunjukkan bahwa pemberian pupuk hayati tidak berpengaruh terhadap tinggi tanaman cabai.

Hasil analisis sidik ragam pada pertumbuhan generatif menunjukkan bahwa faktor lama fermentasi dan interaksi antara lama fermentasi dan dosis pupuk organik cair tidak memberikan pengaruh yang nyata. Hasil uji lanjut pertumbuhan generatif nilai yang tertinggi adalah kontrol positif/NPK tetapi tidak berbeda nyata dengan 
perlakuan pupuk organik cair pada parameter jumlah bunga dan jumlah buah dan berbeda nyata dengan kontrol negatif/tanpa perlakuan.

Hal ini disebabkan pada tahapan produksi, unsur hara pupuk organik cair sudah terdekomposisi sehingga unsur hara dapat diserap dengan baik. Pupuk organik yang diperkaya mikroba aktivator nyata meningkatkan hasil pada tanaman cabai (Addieny, 2011). Keberadaan mikroba yang berfungsi sebagai pupuk hayati sangat penting untuk ketersediaan dan kelarutan hara yang dibutuhkan tanaman untuk pertumbuhan dan peningkatan hasil (Gentili dan Jumpponen, 2005). Mikroba yang teridentifikasi pada pupuk organik cair berdasarkan hasil penelitian Hasriani (2018) yaitu dari golongan Aspergillus yang berperan di alam sebagai perombak atau pendegradasi selulosa. Selain sebagai pendegradasi selulosa, cendawan Aspergillus juga memiliki kemampuan dalam melarutkan fosfat organik menjadi bentuk yang tersedia dan mudah diserap oleh tanaman serta menstimulasi pertumbuhan tanaman (Sugiharto, 2012). Selain Aspergillus, juga terdapat Penicillium yang juga berperan dalam dekomposisi bahan organik. Dekomposisi merupakan proses perubahan secara fisik maupun kimiawi yang sederhana oleh mikroorganisme (Sunarto, 2003).

Bahan utama dalam pembuatan pupuk organik cair adalah kulit pisang dan bonggol pisang. Kulit pisang mengandung kadar air 82,12 \%, C-organik 7,32 \%, N 0,21\%, nisba C/N $35 \%, \mathrm{P}_{2} \mathrm{O}_{5}$ 0,07 \% dan $\mathrm{K}_{2} \mathrm{O} 0,88 \%$ (Sriharti dan Takiyah, 2008). Hasil penelitian Saragih (2016), pupuk organik cair kulit pisang mengandung unsur hara Nitrogen $0,031 \%$, Fosfor 0,0155 \%, dan Kalium 0,0437\%. Bonggol pisang memiliki banyak mata tunas yang didalamnya terdapat banyak giberelin dan sitokinin sehingga dapat memicu pertumbuhan mikroorganisme menguntungkan. Bonggol pisang mengandung beberapa mikroorganisme yang berperan baik dalam penyuburan tanah (Faridah, et al., 2014). MOL bonggol pisang adalah mikroorganisme lokal yang dibuat dari bonggol pisang sebagai penambah nutrisi unsur hara tanaman dan digunakan sebagai biovaktor untuk mempercepat fermentasi (Lepongbulan et al, 2017).

Jenis mikroba yang telah diidentifikasi pada MOL bonggol pisang antara lain Bacillus sp., Aeromonas sp., Aspergillus niger. Mikroba inilah yang akan mengurai bahan organik. Mikroba pada MOL bonggol pisang akan bertindak sebagai dekomposer bahan organik yang akan dikomposkan (Ole, 2013). Bahan lain yang digunakan yaitu air cucian beras dan gula yang berfungsi sebagai sumber energi dan penyubur bakteri. Tinggi dan rendahnya kandungan fosfor tergantung pada kandungan nitrogen dalam pupuk organik cair tersebut, jika nitrogennya tinggi maka fosfornya juga tinggi, begitu sebaliknya. Menurut Stofella dan Khan (2001), bahwa kandungan fosfor berkaitan dengan kandungan $\mathrm{N}$ dalam substrat, semakin besar nitrogen yang dikandung maka mikroorganisme yang merombak fosfor semakin meningkat dan kandungan fosfor dalam subtrat akan digunakan oleh sebagian mikroorganisme untuk membangun selnya.

Unsur $\mathrm{K}$ berperan dalam mengatur turgor (tegangan sel) sehingga tanaman memiliki ketahanan terhadap serangan penyakit. Selain itu unsur K juga berperan dalam mengatur peralihan dari masa vegetatif ke masa generatif, sehingga bunga dan bakal buah tidak gugur, serta warna buah merata (Rahman, 2014). Jumlah yang sedikit pada pupuk organik cair yang diberikan menyebabkan tepi daun melengkung 
ke bawah yang dimulai dari daun tua. Penelitian Ortas (2013) pada tanaman sayuran termasuk cabai, hasil respons terhadap kalium sangat penting bagi kualitas tanaman. Hasil penelitian Waskito et al (2018) juga menunjukkan bahwa jumlah buah dan bobot buah cabai keriting CK 5 tidak dipengaruh oleh interaksi dosis pupuk NPK dan pupuk hayati, tetapi dipengaruhi oleh dosis pupuk NPK dan konsentrasi pupuk hayati secara mandiri. Hasil ini sejalan dengan penelitian Hapsoh et al. (2017) yang menunjukkan bahwa aplikasi pupuk NPK berpengaruh terhadap panjang buah dan lebih menyebabkan peningkatan hasil tanaman cabai rawit dibanding penambahan kompos.

Parameter berat basah tanaman dan berat basah buah menunjukkan bahwa nilai yang tertinggi adalah kontrol positif/NPK dan berbeda nyata dengan perlakuan pupuk organik cair. Hal ini disebabkan karena kandungan unsur hara yang sangat berbeda antara pupuk organik cair dengan pupuk anorganik/NPK yang digunakan seperti yang telah dijelaskan sebelumnya. Namun, perlakuan pupuk organik cair berbeda nyata dengan kontrol negatif/tanpa perlakuan. Hal ini disebabkan karena unsur hara kalium pada POC lebih tersedia dan dapat dimanfaatkan oleh tanaman cabai. Banyaknya jumlah unsur $\mathrm{K}$ dalam tanah dan seiring dengan bertambahnya waktu akan berpengaruh terhadap kadar K yang sebelumnya telah tersedia di dalam tanah, sehingga dapat meningkatkan serapan $\mathrm{K}$ oleh tanaman pada akhirnya akan berpengaruh terhadap biomassa produksi tanaman cabai (Widowati et al., 2007). Kandungan K sebesar $2.41 \%$ pada fermentasi 15 hari dan $3.22 \%$ pada fermentasi 30 hari sedikit banyaknya mendekati kategori standar mutu kandungan kalium yaitu 3-6\% menurut Peraturan Menteri Pertanian No. 70 Tahun 2011.

Dampak dari penggunaan pupuk anorganik yaitu menghasilkan peningkatan produktivitas tanaman yang cukup tinggi. Namun penggunaan pupuk anorganik dalam jangka yang relatif lama umumnya berakibat buruk pada kondisi tanah. Tanah menjadi cepat mengeras sehingga sulit ditembus akar, kurang mampu menyimpan air dan cepat menjadi asam yang pada akhirnya akan menurunkan produktivitas tanaman (Indrakusuma, 2000). Penggunaan pupuk buatan (anorganik) secara terusmenerus juga dapat menipiskan ketersediaan unsur-unsur mikro seperti seng, besi, tembaga, mangan, magnesium, molibdenum, dan boron. Kekurangan nutrisi tersebut mengakibatkan tanaman menjadi kerdil, produksinya menurun, dan rentan terhadap hama atau penyakit, sehingga produktivitas pemupukan menjadi berkurang. Maka dari itu salah satu cara untuk mengurangi dampak negatif dari penggunaan bahan kimia secara berlebihan adalah dengan memperbesar porsi penggunaan bahan-bahan organik (Marpaung, 2014).

Faktor lain yang mempengaruhi tumbuh kembang tanaman ditempat penelitian adalah intensitas curah hujan yang masih cukup tinggi sehingga menyebabkan pelindian terhadap unsur hara di dalam tanah dan pupuk organik cair yang diaplikasikan terhadap tanaman sehingga mempengaruhi pertumbuhan dan hasil tanaman. Anwar et al (2015) menyatakan bahwa curah hujan merupakan unsur iklim yang tingkat fluktuatifnya tinggi dan pengaruhnya terhadap produksi tanaman cukup signifikan. Serupa dengan kondisi di tempat penelitian yang fluktuaktif curah hujannya juga masih cukup tinggi, sehingga unsur hara dalam tanah terbawa oleh air hujan dan tidak dapat diserap akar secara optimal sehingga mempengaruhi 
pertumbuhan dan hasil produksi dari tanaman. Latiri et al (2010) juga memaparkan bahwa curah hujan juga berkorelatif tinggi terhadap komponen hasil suatu tanaman.

Curah hujan yang tinggi berkaitan dengan kelembaban udara yang tinggi pula yang mempengaruhi tanaman. Hal ini sesuai dengan pernyataan Setiawan et al (2012), kelembaban udara sangat berpengaruh terhadap transpirasi sehingga penting bagi tanaman cabai rawit. Kelembaban udara yang rendah cenderung meningkatkan transpirasi tanaman tetapi jika kelembaban udara relatif tinggi, transpirasi akan rendah tetapi pengaruh lainya yaitu pada kelembaban udara yang tinggi menciptakan kondisi yang sesuai bagi perkembangan berbagai jenis hama dan penyakit. Selain faktor lingkungan, cara pengaplikasian pupuk juga mempengaruhi hasil penelitian. Pemberian pupuk organik cair (POC) harus memperhatikan konsentrasi atau dosis yang diaplikasikan terhadap tanaman. Dari beberapa penelitian menunjukan bahwa pemberian POC melalui daun memberikan pertumbuhan dan hasil tanaman yang lebih baik dari pada pemberian melalui tanah (Hanolo, 1997). Semakin tinggi konsentrasi atau dosis pupuk yang diberikan, maka kandungan unsur hara yang diterima oleh tanaman akan semakin tinggi, begitu pula dengan semakin seringnya frekuensi aplikasi pupuk daun yang dilakukan pada tanaman, maka kandungan unsur hara juga semakian tinggi. Pemberian pupuk yang berlebihan akan menimbulkan gejala kelayuan (Suwandi \& Nurtika, 1987).

\section{KESIMPULAN}

1. Dosis pupuk organik cair berpengaruh nyata terhadap pertumbuhan vegetatif (pertumbuhan panjang akar, tinggi batang dan jumlah daun tanaman cabai rawit)

2. Pertumbuhan generatif (rata-rata jumlah bunga, jumlah buah, berat basah tanaman, dan berat basah buah), tanaman cabai rawit menunjukkan bahwa faktor dosis memberikan pengaruh yang nyata terhadap jumlah bunga, jumlah buah, berat basah tanaman, dan berat basah buah cabai rawit.

\section{UCAPAN TERIMA KASIH}

Ucapan terima kasih disampaikan kepada Rektor Universitas Negeri Makassar dan ketua Lembaga Penelitian dan Pengabdian kepada Masyarakat Universitas Negeri Makassar atas dana hibah penelitian PNBP Fakultas yang diberikan pada tahun 2019.

\section{DAFTAR PUSTAKA}

Addieny, L. (2011). Efektivitas Penggunaan Pupuk Organik yang Diperkaya Mikrob Aktivator dalam Mengatur Keseimbangan Tajuk dan Akar Tanaman Cabai (Capsicum annuum L.). Skripsi. IPB. Bogor

Anwar, M. R, Liu D. L, Farquharson, R, Macadam, I., Abadi, A., Finlayson, J., Wang, B., dan Ramilan, T. (2015). Climate Change Impacts On Phenology and Yield of Five Broadacre Crop at Four Climatologically Distinct Locations in Australia. Agricultural Systems 132: 133-144.

Badan Pusat Statistik Republik Indonesia. (2011). Luas Panen, Produksi dan Produktivitas Cabai, 2009-2010, www.bps.go.id. Diakses pada 10 Januari 2018.

Faridah, A., Sumiyati, S. \& Handayani, D. S. (2014). Studi Perbandingan Pengaruh Penambahan Aktivator Agri Simba dengan MOL Bonggol Pisang terhadap 
Kandungan Unsur Hara Makro (CNPK) Kompos Dari Blotong (Sugarcane Filter Cake) dengan Variasi Penambahan Kulit Kopi. Jurnal Teknik Lingkungan, 3(1), 19 .

Gentili, F., and A. Jumpponen. (2005). Handbook of Microbial Fertilizers. Rai MK, editor. The Hawort Press, Inc: New York (US).

Golzc A, Kujawski P, Markiewicz B. (2012). Yielding of red pepper (Capsicum annuum L) under the influence of varied potassium fertilization. J Acta Scientiarum Polanorum-Hortorum Cultus. 11(4):3-15

Hadisuwito, S. (2012). Membuat Pupuk Organik Cair. Jakarta: PT. Agro Media Pustaka. Hanolo. (1997). Tanggapan Tanaman Selada dan Sawi Terhadap Dosis dan Cara Pemberian Pupuk Cair Stimulan. Jurnal Agrotropika I. Hal 25 - 29.

Hapsoh, Gusmarwatati, Al Ichsan Amri, dan Asty Diansyah. (2017). Respons Pertumbuhan dan Produksi Tanaman Cabai Keriting (Capsicum annuum L.) terhadap Aplikasi Pupuk Kompos dan Pupuk Anorganik di Polibag. Jurnal Hortikultura Indonesia 8 (3).

Hasriani. (2018). Analisis Kandungan Unsur Hara Makro Cairan Fermentasi Limbah Pisang (Musa paradisiaca L.). Skripsi belum diterbitkan. Universitas Negeri Makassar: Makassar.

Indrakusuma. (2000). Proposal Pupuk Organik Cair Supra Alam Lestari. PT Surya Pratama Alam: Yogyakarta.

Karim, H., Arifin, A.N., Suryani, A.I. (2016). Seleksi Bakteri Antagonis Asal Rizosfer Tanaman Cabai (Capsicum sp) untuk Menekan Penyakit Layu Fusarium secara in vitro. Jurnal Sainsmat, hal 152-156 E-ISSN 2579-5686, ISSNp 2086-6755.

Karim, H., Suryani, A.I., Yusuf, Y., Hasriani. (2018). Analisis Kandungan Unsur Hara Makro dan Karakterisasi Jamur dari Cairan fermentasi Limbah Pisang . Prosiding Semnas Lemlit UNM. ISBN: 978-602-5554-71-1.

Latiri, K., Lhomme J. P., Annabi, M., dan Setter T. L. (2010). Wheat Production in Tunisia: Progress, Inter-Annual Variability, and Relation to Rainfall. Eur J Aragon 33: 33-42.

Lepongbulan, W., Vanny M.A Timow, dan Anang Wahid M. Diah. (2017). Analisis Unsur Hara Pupuk Organik Cair dari Limbah Ikan Mujair (Oreochromis mosambicus) Danau Lindu dengan Variasi Volume Mikroorganisme Lokal (MOL) Bonggol Pisang. Jurnal Akademika Kimia Volume 6 No.2.

Mahasari, R. (2008). Pengaruh Beberapa Pupuk Organik Terhadap Pertumbuhan dan Serapan N Serta P Tanaman Bit (Beta vulgaris L.) dan Selada Head (Lactuca sativa L.) pada Humic Dystrudept Cisarua. Skripsi. Fakultas Pertanian Institut Pertanian Bogor: Bogor.

Marpaung, AE. (2014). Pemanfaatan Pupuk Organik Padat dan Pupuk Organik Cair dengan Pengurangan Pupuk Anorganik terhadap Pertumbuhan Tanaman Jagung (Zea mays L.). Jurnal Saintech Vol. 06 No. 04.

Munadjim. (1988). Teknologi Pengolahan Pisang,. Gramedia: Jakarta.

Ole, M. B. B. (2013). Penggunaan Mikroorganisme Bonggol Pisang (Musa paradisiciaca) sebagai Dekomposer Sampah Organik. Skripsi. Program Studi Biologi Universitas Atma Jaya:Yogyakarta. 
Ortas, I. (2013). Influences of Nitrogen and Potassium Fertilizer Rates on Pepper and Tomato Yield and Nutrient Uptake Under Field Conditions. Academic Journals. 8 (23): 1048-1055.

Parnata, Ayub. S. (2004). Pupuk Organik Cair Aplikasi dan Manfaatnya. AgroMedia Pustaka: Jakarta.

Rahman, D.T., (2014). Unsur Hara Makro dan Mikro yang Dibutuhkan oleh Tanaman, https://organichcs.com/2014/05/03/unsur-makro-dan-mikro-yang-dibutuhkanoleh-tanaman/, diakses tanggal 10 Januari 2018.

Rizqiani, N. F., E. Ambarwati, dan N. W. Yuwono. (2006). Pengaruh Dosis dan Frekuensi Pemberian Pupuk Organik Cair Terhadap Pertumbuhan dan Hasil Buncis (Phaseolus vulgaris L.) Dataran Rendah, Jurnal Ilmu Tanah dan Lingkungan Vol. 7 No.1 (2007) p: 43-53 Fakultas Pertanian UGM: Yogyakarta.

Roidah, IS. (2013). Manfaat Penggunaan Pupuk Organik Untuk Kesuburan Tanah. Jurnal Universitas Tulungagung Bonorowo Vol. 1 No.1.

Saragih, EF. (2016) . Pengaruh Pupuk Cair Kulit Pisang Kepok (Musa paradisiaca forma typica) terhadap Pertumbuhan Tanaman Sawi Caisim (Brassica juncea L.). Skripsi. Program Studi Pendidikan Biologi Jurusan Pendidikan Matematika dan Ilmu Pengetahuan Alam Fakultas Kegurusan dan Ilmu Pendidikan Universitas Sanata Dharma: Yogyakarta.

Setiawan, A. Budi, Purwanti S., dan Toekidjo. (2012). Pertumbuhan dan Hasil Benih Lima Varietas (Capsicum annuum L.) Di Dataran Menengah. Yogyakarta. Fakultas Pertanian, Universitas Gajah Mada Yogyakarta.

Sriharti dan Takiyah Salim. (2008). Pemanfaatan Limbah Pisang untuk Pembutan Kompos Menggunakan Komposer Rotary Drum. Yogyakarta: Balai Besar Pengembangan Teknologi Tepat Guna LIPI.

Stofella, PJ and B.A Khan (2001). Compost Utilization in Horticultural Cropping Systems. Lewis Publisher: London.

Sugiharto, A. (2012). Isolasi dan Seleksi Kapang Halotoleran serta Aplikasinya pada Tanaman Padi (Oryza Sativa L.) Varietas Ciherang. Tesis. Program Studi Biologi FMIPA Universitas Indonesia.

Sunarto. (2003). Peranan Dekomposisi dalam Proses Induksi pada Ekosistem Laut. Disertasi. Pengantar Falsafah Sains. Program Pascasarjana IPB.

Suwandi dan Nurtika. (1987). Pengaruh pupuk biokimia "Sari Humus" pada Tanaman Kubis. Buletin Penelitian Hortikultura 15 (20): 213-218.

Wahyuningratri, A., Aini, N., dan Heddy, S. (2017). Pengaruh Konsentrasi dan Frekuensi Pemberian Pupuk Hayati terhadap Pertumbuhan dan Hasil Cabai Besar (Capsicum annuum L.). Jurnal Produksi Tanaman. Vol.5 No.1

Wardhani, S., Purwani, K. I., dan Anugerahani,W. (2014). Pengaruh Aplikasi Pupuk Hayati terhadap Pertumbuhan dan Produktivitas Tanaman Cabai Rawit (Capsicum frutescens L.) Varietas Bhaskara di PT Petrokimia Gresik. Jurnal Sains dan Seni Pomits Vol. 2 No.1.

Waskito, H., A. Nuraini, dan N. Rostini. (2018). Respon Pertumbuhan dan Hasil Cabai Keriting (Capsicum annuum L.) Ck5 akibat Perlakuan Pupuk NPK dan Pupuk Hayati. Jurnal Kultivar Vol. 17 (2). 
Widowati, Astutik, E. Nogo. (2007). Efisiensi Pemupukan K dengan Bokashi Tinja pada Cabai Besar. Buana Sains. 7(2): 177-185. 